\title{
Mob rulers and part-time cleaners: two reef fish associations at the isolated Ascension Island
}

\author{
R.A. MORAIS ${ }^{1}$, J. BROWN ${ }^{2}$, S. BEDARD ${ }^{3}$, C.E.L. FERREIRA ${ }^{4}$, S.R. FLOETER ${ }^{1}$, J.P. QUIMBAYO ${ }^{1}$, L.A. ROCHA ${ }^{3}$ \\ AND I. SAZIMA ${ }^{5}$ \\ ${ }^{1}$ Marine Macroecology and Biogeography Lab, Departamento de Ecologia e Zoologia, Centro de Ciências Biológicas, Universidade \\ Federal de Santa Catarina, Florianópolis - SC, Brazil, ${ }^{2}$ Conservation Department, Ascension Island Government, Georgetown, \\ Ascension Island, UK, ${ }^{3}$ California Academy of Sciences, San Francisco, CA, USA, ${ }^{4}$ Reef Systems Ecology and Conservation Lab, \\ Departamento de Biologia Marinha, Instituto de Biologia, Universidade Federal Fluminense, Niterói, RJ, Brazil, ${ }^{5}$ Museu de Zoologia, \\ Universidade Estadual de Campinas, Campinas, SP, Brazil
}

\begin{abstract}
Isolated oceanic islands may give rise not only to new and endemic species, but also to unique behaviours and species interactions. Multi-species fish interactions, such as cleaning, following, mob-feeding and others are understudied in these ecosystems. Here we present qualitative and quantitative observations on cleaning and mob-feeding reef fish associations at the isolated Ascension Island, South Atlantic Ocean. Cleaning interactions were dominated by juveniles of the facultative fish cleaners Bodianus insularis and Pomacanthus paru, with lesser contributions of Chaetodon sanctaehelenae, Thalassoma ascensionis and the cleaner shrimp Lysmata grabhami. Two types of feeding mobs were consistently identified: less mobile mobs led by the surgeonfish Acanthurus bahianus and A. coeruleus and the more mobile mobs led by the African sergeant Abudefduf hoefleri. This is the first record of A. hoefleri from outside of the Eastern Atlantic and also the first report of this species displaying mob-feeding behaviour. The principal follower of both mob types was the extremely abundant Melichthys niger, but the main aggressor differed: Stegastes lubbocki, a highly territorial herbivore, was the main aggressor of Acanthurus mobs; and Chromis multilineata a territorial fish while engaged in egg parental care, was the principal aggressor towards Abudefduf mobs. Our study enhances the scarce information on reef fish feeding associations at the isolated Ascension Island and at oceanic islands in the Atlantic in general.
\end{abstract}

Keywords: fish associations, cleaning interactions, mob-feeding, Ascension Island

Submitted 2 March 2016; accepted 12 July 2016; first published online 8 August 2016

\section{INTRDDUCTION}

Isolated oceanic islands pose challenges to colonization by marine species while, at the same time, providing evolutionary opportunities for speciation of those few successful colonists (Vermeij, 2004; Dawson, 2016). As a result, oceanic islands are poorer in species richness and often contain more endemic species than continental shelves or islands (Robertson, 2001; Vermeij, 2004; Dawson, 2016). These particularities in isolated communities' species pools can also foster the emergence of unique behaviours and interactions, as has been documented for marine species at South Atlantic oceanic islands (Lubbock, 1980; Sazima et al., 2003, 2007; Sazima \& Sazima, 2004; Gasparini et al., 2008). Some of these interactions can have important ecosystem-wide consequences, for example, by enhancing the energetic flux among trophic compartments in these species-depauperate systems (Sazima et al., 2003, 2006; Sazima \& Sazima, 2004).

Corresponding author:

R.A. Morais

Email: renatomoraisaraujo@gmail.com
Reef fishes engage in a variety of intra- and inter-specific interactions, both among themselves and with invertebrates. Partnerships among fishes include cleaning symbiosis, associations that overwhelm territorial species (mobbing or mob-feeding), hunting by riding, aggressive mimicry and nuclear-follower interactions (Randall \& Randall, 1960; Ormond, 1980; Aronson, 1983; Sikkel \& Hardison, 1992; Côté, 2000; Lukoschek \& McCormick, 2000; Sazima, 2002; Grutter, 2005; Randall, 2005; Karplus, 2014). Albeit all such interactions occur in isolated oceanic islands (Barlow, 1974; Sazima et al., 2007, 2010a, 2010b; Quimbayo et al., 2012, 2014), our work focuses on two of them: cleaning and mob-feeding.

Cleaning behaviour involves cleaner organisms (fishes and shrimps) that pick and eat ectoparasites, damaged tissue and mucus from other animals: the clients (Losey, 1972; Grutter, 2005). Cleaning interactions have a positive effect on the client's overall health, growth rates and reproductive and recruitment success (Cheney \& Côté, 2003; Grutter, 2005; Sun et al., 2015). Most cleaner fishes are facultative cleaners, while only a handful of species are obligates. Facultative cleaners are most often juveniles that are not reliant upon cleaning as their primary means of obtaining food ('part-time cleaners'), whereas obligate cleaners, in contrast, clean throughout their life and acquire their food mostly, or entirely, from their 
clients. We herein use this well-established terminology according to overviews of cleaning symbiosis and a number of often-cited references that propose and/or employ these two categories (Itzkowitz, 1979; Côté, 2000; Grutter, 2005; Arnal et al., 2006; Floeter et al., 2007b; Francini-Filho \& Sazima, 2008; Cheney et al., 2009; Soares et al., 2012).

Besides cleaning, another common multi-species association observed in tropical reef habitats is mobbing in large shoals, a feeding tactic employed to overcome the territorial defences of other fish (Barlow, 1974; Robertson et al., 1976; Foster, 1985; Reinthal \& Lewis, 1986). Feeding mobs decrease per capita suffered attacks from territorial fishes and increase substrate bite-rates and, therefore, food resource acquisitions (Robertson et al., 1976; Foster, 1985; Reinthal \& Lewis, 1986). Several species of surgeonfish, parrotfish, damselfish and wrasse are known to feed in mob shoals within other fish species' territories, both in the Atlantic and Pacific (Keenleyside, 1979; DeLoach, 1999). Food resources most often sought by these mobbing shoals are algae and eggs (DeLoach, 1999; Randall, 2002; Sazima et al., 2013).

There have been several studies on cleaning symbiosis, mob-feeding and nuclear-follower feeding interactions (opportunistic fishes that follow substrate-disturbing fishes), but most of these were conducted along coastal reefs, leaving oceanic islands woefully understudied (but see von Eibl-Eibesfeldt, 1955; Gasparini \& Floeter, 2001; Sazima et al., 2007; Gasparini et al., 2008; Bertoncini et al., 2009). At Ascension island, particularly, knowledge on these interactions is restricted to mentions and pictures in Lubbock (1980); Bingeman \& Bingeman (2005) and Wirtz et al. (2017). As these isolated environments constitute evolutionary units on their own (Dawson, 2016), they might also be engines for the appearance of novel interactions among species, some with uninvestigated ecosystem consequences (Sazima et al., 2003, 2007; Sazima \& Sazima, 2004; Gasparini et al., 2008).
Therefore, our objective is to partially fill the gap that exists in our understanding of isolated islands in the Atlantic. To achieve this, here we present qualitative and quantitative data on reef fish associations in one of the most isolated tropical islands in the world: Ascension Island, South Atlantic. We focused on three key questions about cleaning interactions and mob-feeding behaviour: (1) Which species are the main reef cleaners and clients around the island, what are the relative contributions of both these associates to cleaning interactions, and are these contributions proportional to their abundances? (2) What are the main participants of feeding mobs (mobbers, followers and aggressors) and how strong are the interactions among them? (3) What is the probability of occurrence of cleaning interactions and mob-feeding behaviour per unit of time and area on Ascension's reefs?

\section{METHDDS}

Cleaning and mob-feeding behaviours were recorded over a 12-day expedition to Ascension Island, South Atlantic Ocean $\left(7^{\circ} 56^{\prime} \mathrm{S} 14^{\circ} 25^{\prime} \mathrm{W}\right)$ in August 2015 and from previous and subsequent observations by one of the authors (J. Brown). All observations were made while scuba diving at depths of 5-15 $\mathrm{m}$ at four sites around Ascension: English Bay (including One Hook), where most of the diving was conducted, Comfortless Cove, Northeast Point and Boatswain Bird Island (Figure 1).

\section{Cleaning interactions}

Cleaning events were recorded opportunistically while diving, with the use of direct observations, photographs and video footages. As no standardized search method was employed (i.e. by observation time), only relative contribution of

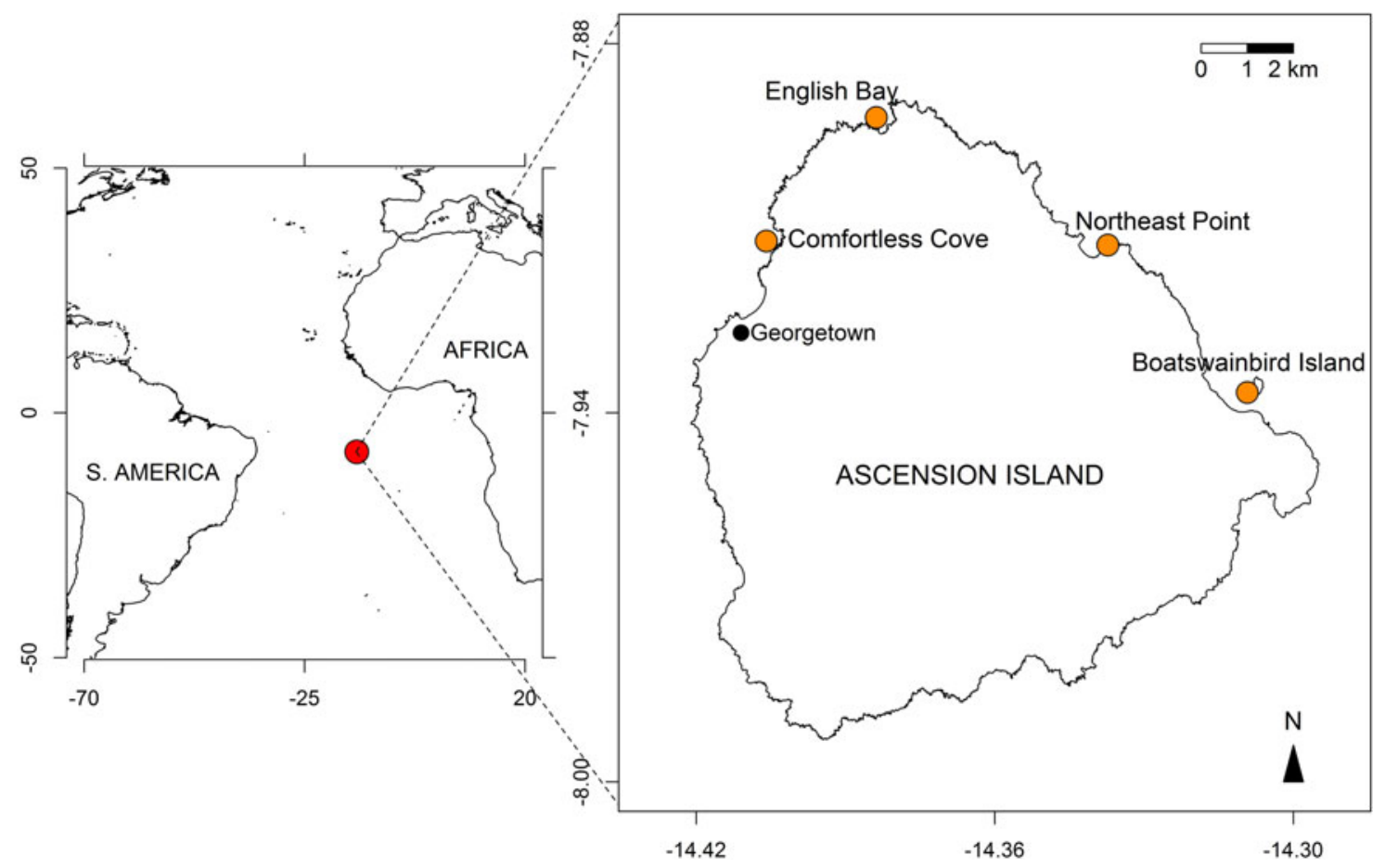

Fig. 1. Maps showing the location of Ascension Island in the South Atlantic Ocean $\left(7^{\circ} 56^{\prime} \mathrm{S} 14^{\circ} 25^{\prime} \mathrm{W}\right.$; red circle in left panel) and the sampled sites around the island (orange circles, right panel). 
cleaning by each cleaner could be derived. We calculated it as the number of cleaning events in which this cleaner was involved relative to the total number of recorded cleaning events. Thus, if one cleaner species was observed cleaning the same client species in two distinct events (i.e. separated from each other in time or space), these events were considered as independent and therefore counted as two. The abundance of cleaners and clients was estimated from underwater visual surveys conducted along standard $20 \times 2 \mathrm{~m}$ strip transects (Krajewski \& Floeter, 2011; Pinheiro et al., 2011). In this sampling method, a diver swims unfolding a tape and recording, counting and estimating the size of large, fast swimming and water column-dwelling fishes. After reaching the end of the $20 \mathrm{~m}$ layout, the diver returns retracting the tape and employing the same procedures for small, benthic associated and cryptic fishes (Floeter et al., 2007a; Krajewski \& Floeter, 2011).

\section{Mob-feeding behaviour}

Mob-feeding events were recorded and quantified from video recordings using whole group focal animal sampling (Lehner, 1979). When a mob was detected, the diver started recording it as the fishes swam and/or fed and continued for $\sim 3$ min or up to the point at which the mob left the area. We consider mob-feeding events as those in which a group of individuals from a nuclear fish species (i.e. the species which leads the mob) fed over the substrate while being followed by opportunist fish species and chased away from either feeding or reproductive territories by territorial fish species. During mob-feeding events, we identified each species involved and recorded the species' role (whether nuclear, hereafter referred to as 'mobber', follower, or aggressor), its abundance, and the intensity of the interactions. Two types of interactions were identified: following, which intensity was quantified as the sum of the time each individual followed the feeding mob; and aggressive (or agonistic), which intensity was quantified as the sum of the number of chases each individual made towards the feeding mob. We also estimated the substratum bite rate of the entire mob by counting the bite rate of randomly sampled feeding individuals and averaging and multiplying it by the total number (usually $3-5$ ) of individuals feeding on the mob.

\section{Probability of occurrence of interactions}

Additionally, to understand how common are cleaning and mob-feeding events, we used remote filming of fixed areas of the reef per unit of time. From this we obtained the probability of occurrence of these interactions per $\mathrm{m}^{2}$ of reef during a $10 \mathrm{~min}$ time period. The method employed consisted of positioning portable cameras focused on small areas of the reef and recording over 15 min per sample (Longo \& Floeter, 2012; Longo et al., 2014). Cleaning interactions were recorded in an area of $2 \mathrm{~m}^{2}$ due to the generally small size of cleaner fishes. Mob-feeding events, however, are highly mobile in nature and therefore were recorded over a larger area of $6 \mathrm{~m}^{2}$. Spatial replicates assured the representativeness of this type of sampling under the work conditions (daytime hours during the winter). Since cameras were generally deployed in such a way as to minimize the occurrence of shadowed ledges, vertical walls and small caves (Longo \& Floeter,
2012), frequency of cleaning interactions was possibly underestimated.

\section{Statistical tests}

To answer if cleaners cleaned proportionally to their abundances, we used a Chi-square test. Differences in abundance and bite-rate between mobs were tested through Student's $t$-tests.

\section{RESULTS}

\section{Cleaning interactions}

We recorded five cleaner species at Ascension (Figure 2): four reef fishes, the Island hogfish Bodianus insularis - juveniles only (Figure 2A, B), the French angelfish Pomacanthus paru - also juveniles only (Figure $2 \mathrm{C}-\mathrm{E}$ ), the St Helena butterflyfish Chaetodon sanctaehelenae (Figure $2 \mathrm{E}$ ) and the Ascension wrasse Thalassoma ascensionis - mostly as juveniles (Figure $2 \mathrm{~F}$ ); as well as one crustacean: the white-striped cleaner shrimp Lysmata grabhami (Figure $2 \mathrm{G}, \mathrm{H}$ ). All of them are facultative cleaners, and only the angelfish and the shrimp are widely distributed. The Island hogfish is endemic to the Mid-Atlantic Ridge Islands (Ascension, St Helena and St Paul's Rocks); the butterflyfish is endemic to Ascension and St Helena and the Ascension wrasse is endemic to Ascension.

For three of these cleaners, we recorded cleaning stations: the hogfish and the angelfish - habitually near the bottom or in the water column (Figure $2 \mathrm{~A}-\mathrm{D}$ ) and the shrimp only in rock crevices (Figure $2 \mathrm{G}, \mathrm{H}$ ). Cleaning interactions were initiated by the potential clients, which posed or adopted particular colours in front of the cleaner or the cleaning station (Figure $2 \mathrm{E}$ ). The hogfish was the only species that formed groups while cleaning (up to about 15 juvenile individuals; Figure 2A), whereas other species cleaned mostly individually. We also recorded the angelfish and the butterflyfish sharing the same client (Figure $2 \mathrm{E}$ ) on one occasion.

In a total of 64 events of cleaning interactions, the highest proportion was led by the Island hogfish (35.9\%), followed by the French angelfish $(28.1 \%)$, the white-striped cleaning shrimp (14.1\%), the St Helena butterflyfish and the Ascension wrasse (10.9\% each). Both the angelfish and the hogfish had the most diverse pool of clients (10 species including the green sea turtle Chelonia mydas cleaned by the hogfish), followed by the wrasse (six), and the butterflyfish and the shrimp (five species each, Figure 3). Proportion of cleaning interactions did not follow cleaner abundance $\left(\chi^{2}=16.84, \mathrm{df}=3, P<0.001\right)$. The most abundant cleaner, the Ascension wrasse, had the smaller contribution to overall cleaning events while the less abundant cleaner, the French angelfish, had the second highest contribution (Table 1).

A total of 19 fish client species in 12 families and one sea turtle were recorded (Table 1). Five species of morays acted as clients, followed by groupers, squirrelfish and filefish (two species each), whereas other fish groups had one client each (Table 1). Eight client species were piscivores, four were omnivores and the remainder trophic groups were planktivores, herbivores and mobile invertebrate predators (two or three species each, Table 1). The abundance of clients, as measured from underwater visual surveys, varied from 0.0003 to 1.19 

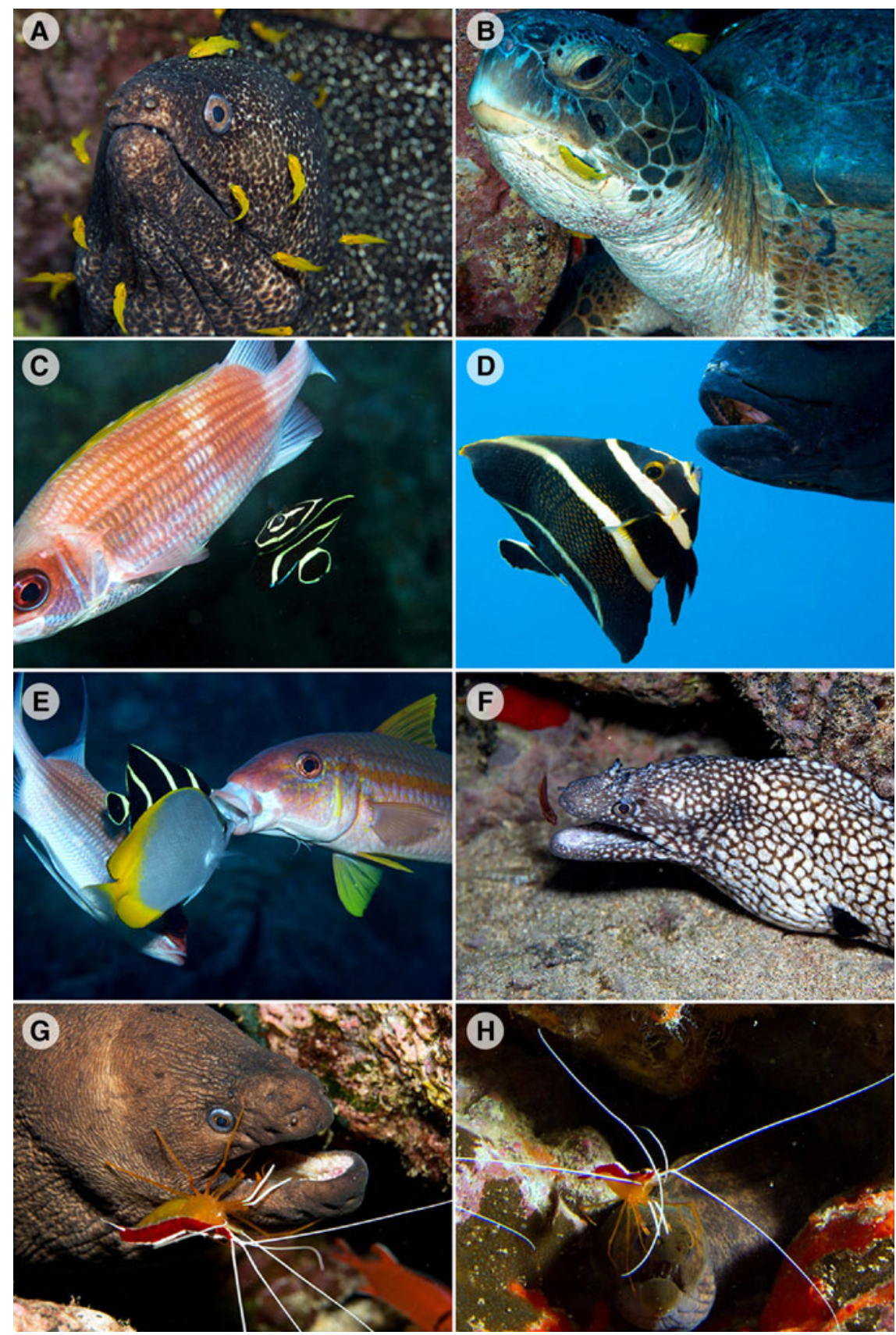

Fig. 2. Interactions between cleaners and clients at Ascension Island's reefs. (A) At a cleaning station, Island hogfish (Bodianus insularis) juveniles cluster to clean the head of a spotted moray (Gymnothorax moringa). (B) Two juvenile hogfish clean the head of a green sea turtle (Chelonia mydas); the top one is nibbling at a lesion, not visible in the photo. (C) A juvenile French angelfish (Pomacanthus paru) inspects a posing squirrelfish (Holocentrus adscensionis). (D) An older angelfish cleans the jaw of a black jack (Caranx lugubris). (E) A juvenile angelfish and an adult St Helena butterflyfish (Chaetodon sanctaehelenae) clean the mouth of a yellow goatfish (Mulloidichthys martinicus). (F) A juvenile Ascension wrasse (Thalassoma ascensionis) inspects the lower jaw of a whitespotted moray (Muraena pavonina). (G) A white-striped cleaner shrimp (Lysmata grabhami) cleans the jaw of a brown moray (Gymnothorax unicolor) in its cleaning station in a crevice. $(\mathrm{H})$ The same shrimp species cleans the snout of a viper moray (Enchelycore nigricans).

individuals $\mathrm{m}^{-2}$. The viper moray (Enchelycore nigricans) was the least abundant client, whereas the brown chromis (Chromis multilineata) was the most abundant (Table 1).

\section{Mob-feeding behaviour}

We consistently identified two types of feeding mobs: those led by the African sergeant (Abudefduf hoefleri) (Figure 4A); and those led by mixed shoals of the barber surgeonfish (Acanthurus bahianus) and blue tang (Acanthurus coeruleus)
(Figure $4 \mathrm{~B}, \mathrm{C}$ ). The black triggerfish, or blackfish (Melichthys niger) was also frequently observed feeding in large groups along the bottom (Figure $4 \mathrm{D}$ ) but, as it neither attracted followers nor was habitually chased by territorial species, its groups were not considered mob-feeders. Additionally, we recorded groups of yellow goatfish (Mulloidichthys martini$c u s$ ) with some (Figure $4 \mathrm{E}$ ) or all (Figure $4 \mathrm{~F}$ ) individuals displaying a dark colouration and an active swimming behaviour closely resembling those of the African sergeant mobs. The goatfish, however, were never observed to feed while shoaling. 


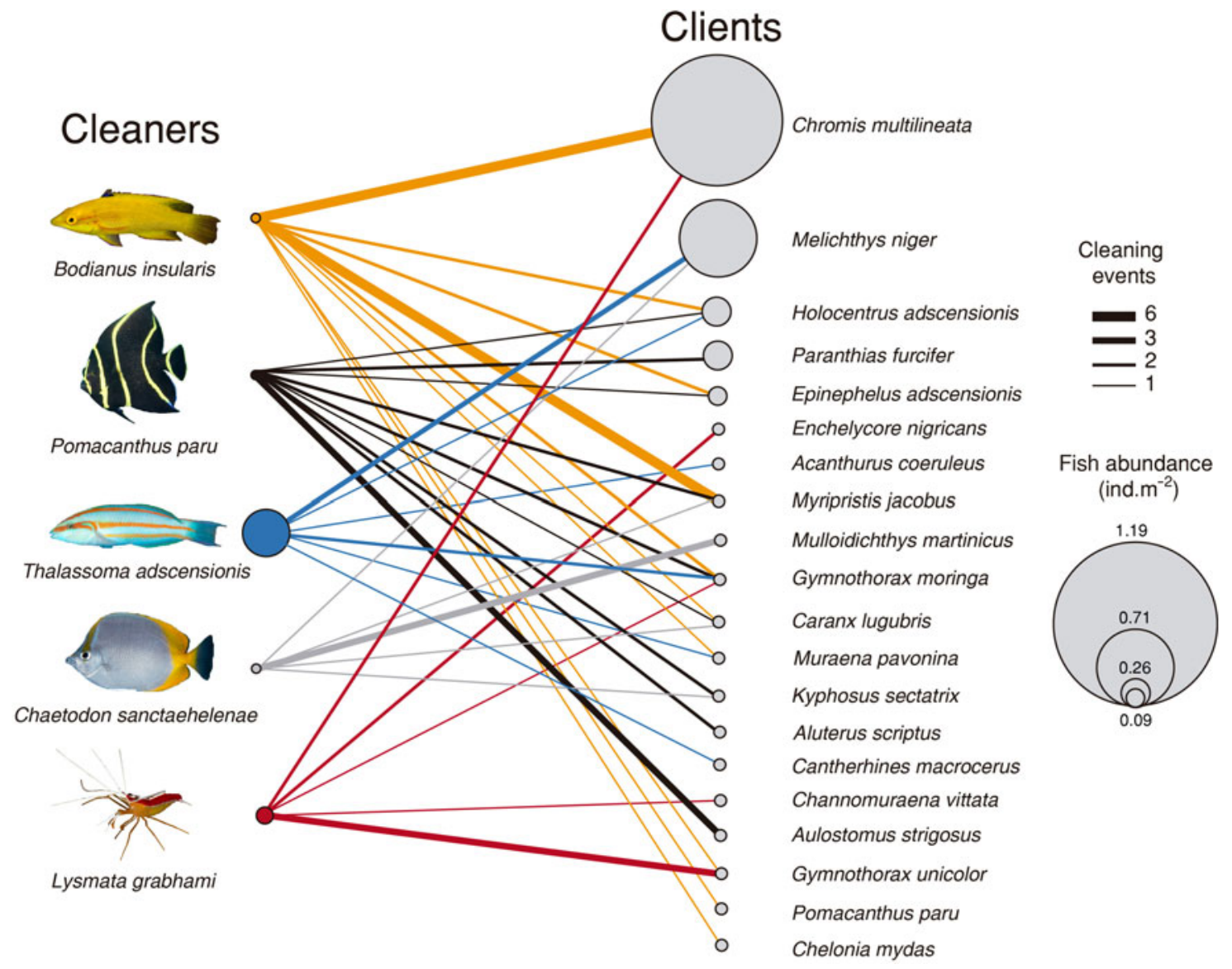

Fig. 3. Cleaner-client interaction network at Ascension Island's reefs. Circle size is proportional to abundance (ind. $\mathrm{m}^{-2}$ ), except for Lysmata grabhami and Chelonia mydas, whose abundance was not quantified. Lines indicate cleaner-client interactions; line width is proportional to the number of cleaning events.

Thirteen mob-feeding events ranging $22-436 \mathrm{~s}$ (mean $=$ $100 \mathrm{~s}$ ) were analysed, six of them led by surgeonfish (Acanthurus spp.) and seven by the African sergeant. While surgeonfish mobs were characterized by simultaneously having individuals simultaneously feeding and swimming, and moved a few metres over several minutes; almost all individuals of the African sergeant mobs engaged in the same activity, temporally interspersing feeding and swimming while moving tens of metres over a few minutes. While follower species intermingled with the mobbers, aggressor species chased the mobbers from the vicinities of the mob (Figure 5).

African sergeant mobs were smaller than surgeonfish mobs (100.6 \pm 12.7 against $175.8 \pm 13.2$ individuals; $t=-4.11, \mathrm{df}=10.8, P=0.0018)$. Mobbers represented, respectively $84 \%$ (only the African sergeant) and $87 \%(71 \%$ the barber surgeonfish and $16 \%$ the blue tang) of individuals, the rest being followers (Figure 6). Aggressive events derived predominantly from territorial damselfishes and targeted more frequently mobbers than followers (Figure 6). The main follower of both mob types was the opportunist blackfish (Figure 6), but the main aggressor differed: the Lubbock's damselfish (Stegastes lubbocki), a highly territorial herbivore, was the main aggressor of surgeonfish mobs (Figure 6B); and the brown chromis, another territorial fish while engaged in egg parental care, was the principal aggressor towards African sergeant mobs (Figure 6A).
Feeding rate also differed between mob types: African sergeant mobs delivered on average $6 \pm 2.4$ bites s $^{-1}$ at substrate, whereas Acanthurus spp. mobs delivered almost 11 times more, $70.4 \pm 10.7$ bites s $^{-1}(t=-5.86, \mathrm{df}=5.5, P=$ 0.0015). Most of these bites were made by the mobbers (91.4 and $99.8 \%$ of total bites in Abudefduf and Acanthurus mobs, respectively), with a smaller proportion opportunistically delivered by followers.

\section{Probability of occurrence of interactions}

In 72 remote videos (totalling 720 min analysed), we recorded only five mob-feeding and one cleaning event, resulting in probabilities of occurrence of respectively 1.16 and $0.69 \%$ of these interactions per $\mathrm{m}^{2}$ during $10 \mathrm{~min}$. Three of the mobs detected were the more mobile African sergeant mobs and two were the less mobile surgeonfish mobs. The only video-recorded cleaning instance was a juvenile Ascension wrasse Thalassoma ascensionis repeatedly cleaning a blue tang Acanthurus coeruleus.

\section{DISCUSSION}

Our study increases the knowledge of reef fish associations at isolated oceanic islands by focusing on one of the most isolated of tropical islands in the world: Ascension Island in the 
Table 1. Number of observed cleaning interactions per cleaner and client species at Ascension Island's reefs. Fish taxonomy follows Nelson (2006) except for Epinephelidae (Craig \& Hastings, 2007). All families are listed in alphabetical sequence, except for the sea turtle.

\begin{tabular}{|c|c|c|c|c|c|c|c|}
\hline \multirow[t]{2}{*}{ Clients } & \multicolumn{7}{|l|}{ Cleaners } \\
\hline & Bodianus insularis & Pomacanthus paru & Chaetodon sanctaehelenae & Thalassoma ascensionis & Lysmata grabhami & Trophic group & Abundance (ind $/ \mathbf{m}^{2}$ ) \\
\hline \multicolumn{8}{|l|}{ Acanthuridae } \\
\hline Acanthurus coeruleus & & & & 1 & & $\mathrm{HB}$ & 0.02 \\
\hline \multicolumn{8}{|l|}{ Aulostomidae } \\
\hline Aulostomus strigosus & & 3 & & & & PS & 0.0009 \\
\hline \multicolumn{8}{|l|}{ Balistidae } \\
\hline Melichthys niger & & & 1 & 2 & & OM & 0.71 \\
\hline \multicolumn{8}{|l|}{ Carangidae } \\
\hline Caranx lugubris & 1 & 1 & 1 & & & PS & 0.02 \\
\hline \multicolumn{8}{|l|}{ Epinephelidae } \\
\hline Epinephelus adscensionis & 2 & 1 & & & & PS & 0.05 \\
\hline Paranthias furcifer & & 2 & & & & $\mathrm{PK}$ & 0.17 \\
\hline \multicolumn{8}{|l|}{ Kyphosidae } \\
\hline Kyphosus sectatrix & & 2 & 1 & & & $\mathrm{HB}$ & 0.003 \\
\hline \multicolumn{8}{|l|}{ Holocentridae } \\
\hline Holocentrus adscensionis & 2 & 1 & & 1 & & IM & 0.26 \\
\hline Myripristis jacobus & 6 & 2 & 1 & & & IM & 0.09 \\
\hline \multicolumn{8}{|l|}{ Pomacanthidae } \\
\hline Pomacanthus paru & 1 & & & & & $\mathrm{OM}$ & 0.004 \\
\hline \multicolumn{8}{|l|}{ Monacanthidae } \\
\hline Aluterus scriptus & & 2 & & & & OM & 0.25 \\
\hline Cantherhines macrocerus & & & & 1 & & OM & 0.04 \\
\hline \multicolumn{8}{|l|}{ Mullidae } \\
\hline Mulloidichthys martinicus & & 2 & 3 & & & IM & 0.003 \\
\hline \multicolumn{8}{|l|}{ Muraenidae } \\
\hline Enchelycore nigricans & & & & & 2 & PS & 0.0003 \\
\hline Channomuraena vittata & & & & & 1 & PS & 0.02 \\
\hline Gymnothorax moringa & 2 & 2 & & 1 & 1 & PS & 0.003 \\
\hline Gymnothorax unicolor & 1 & & & & 3 & PS & 0.0009 \\
\hline Muraena pavonina & 1 & & & 1 & & PS & 0.008 \\
\hline \multicolumn{8}{|l|}{ Pomacentridae } \\
\hline Chromis multilineata & 6 & & & & 2 & PK & 1.19 \\
\hline \multicolumn{8}{|l|}{ Cheloniidae (turtle) } \\
\hline Chelonia mydas & 1 & & & & & - & - \\
\hline Relative contribution & 35.9 & 28.1 & 10.9 & 10.9 & 14.1 & & \\
\hline Client richness & 10 & 10 & 5 & 6 & 5 & & \\
\hline Abundance (ind. $\mathrm{m}^{-2}$ ) & 0.02 & 0.004 & 0.007 & 0.44 & - & & \\
\hline
\end{tabular}

HB, herbivores; IM, mobile invertebrate predators; MC, macrocarnivores; OM, omnivores; PK, planktivores; PS, piscivores. 

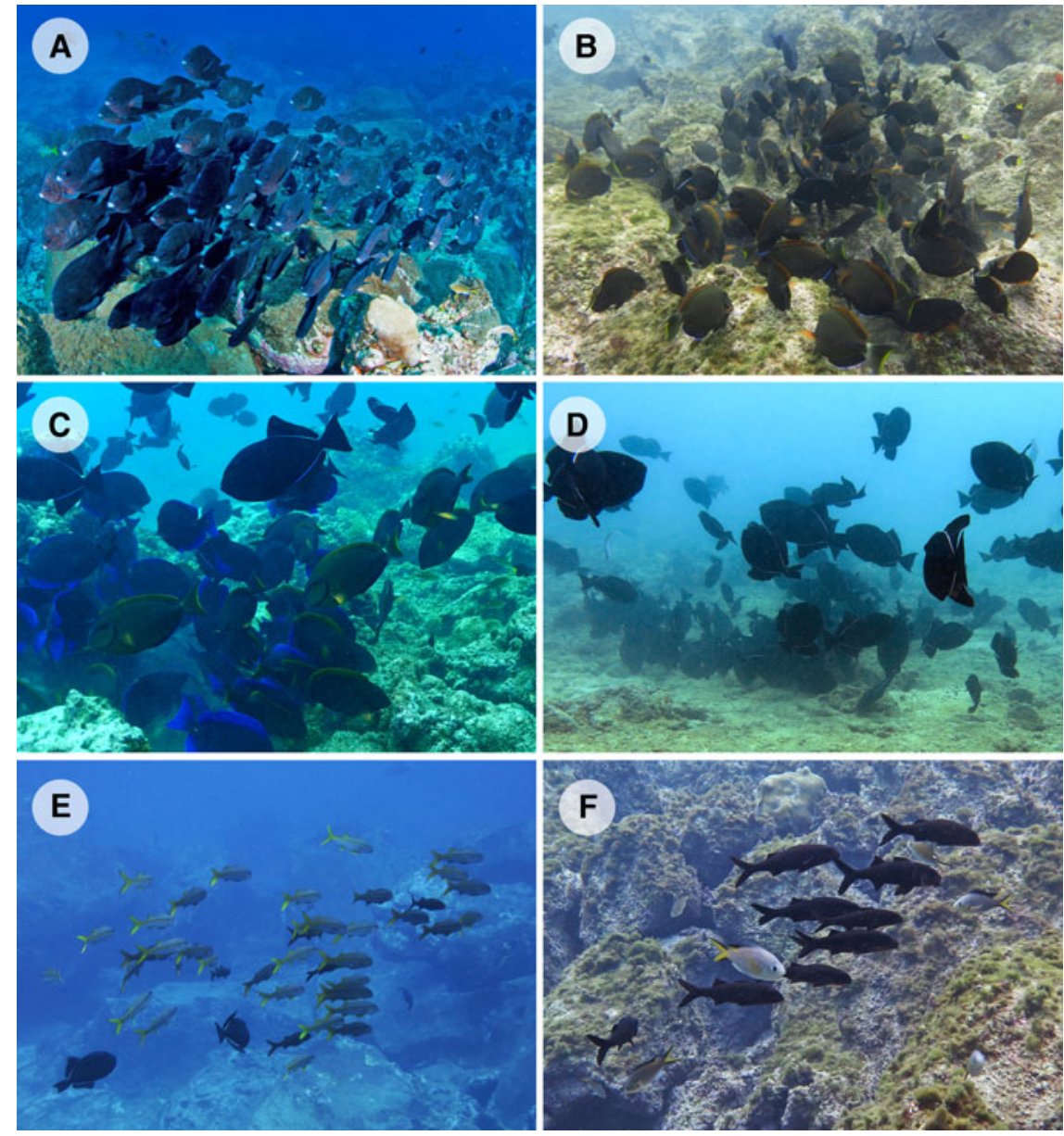

Fig. 4. Mobs of Ascension Island reef fishes. (A) A large feeding mob led by the African sergeant (Abudefduf hoefleri). (B) and (C) Feeding mobs of surgeonfish Acanthurus bahianus and A. coeruleus. Note darkened colour of A. bahianus. (D) A group of the black triggerfish, or blackfish (Melichthys niger) feeding along the bottom. (E) and (F) Shoaling yellow goatfish (Mulloidichthys martinicus) while darkened. Although the latter species was neither recorded displaying feeding mobs, nor feeding in groups, shoaling individuals sometimes displayed the dark colouration characteristic of other mobs.

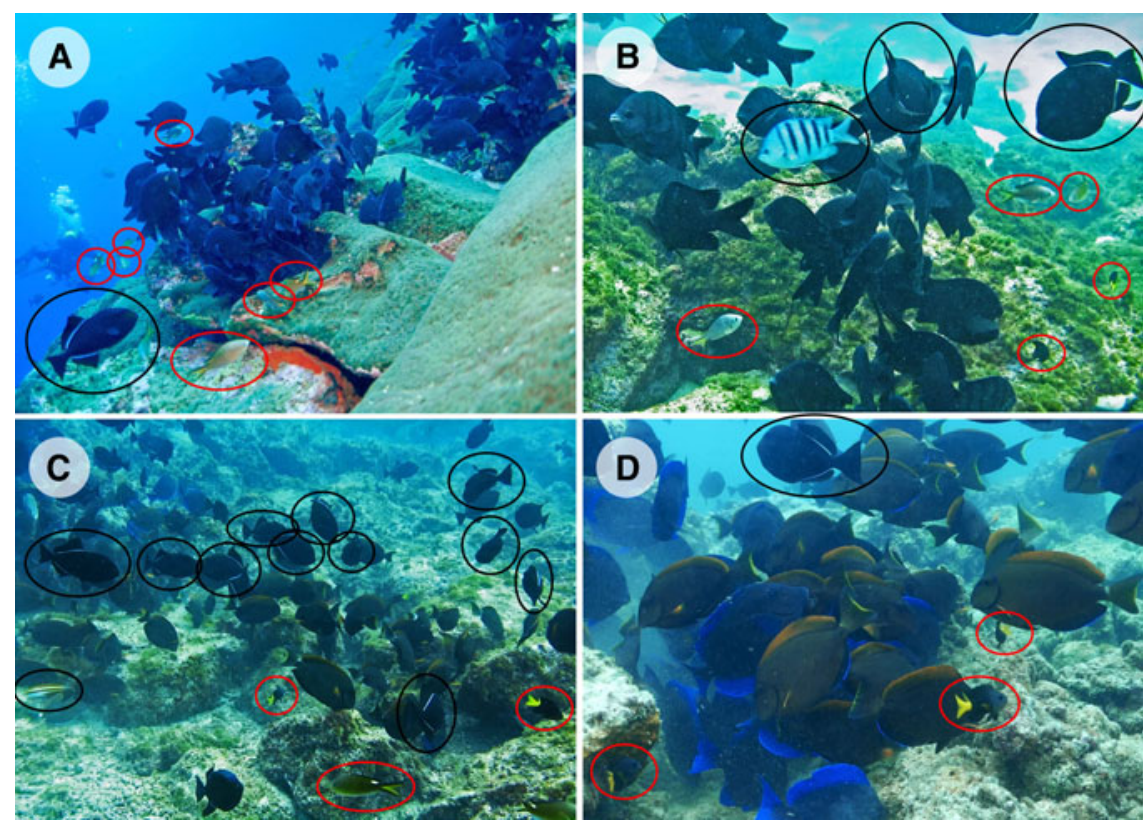

Fig. 5. Participants in reef fish feeding mobs at Ascension Island. (A) and (B): mobs led by the African sergeant (Abudefduf hoefleri). (C) and (D): mobs led by surgeonfish (Acanthurus bahianus and A. coeruleus); note darkened colour of A. bahianus. Black ellipses and circles indicate followers; red ellipses and circles highlight aggressors. Note (in B) a light-coloured sergeant major (Abudefduf saxatilis) intermingling with and following a dark-coloured mob of the African sergeant (the sergeant major was not recorded feeding while within the mob). 
Abudefduf hoefleri mobs
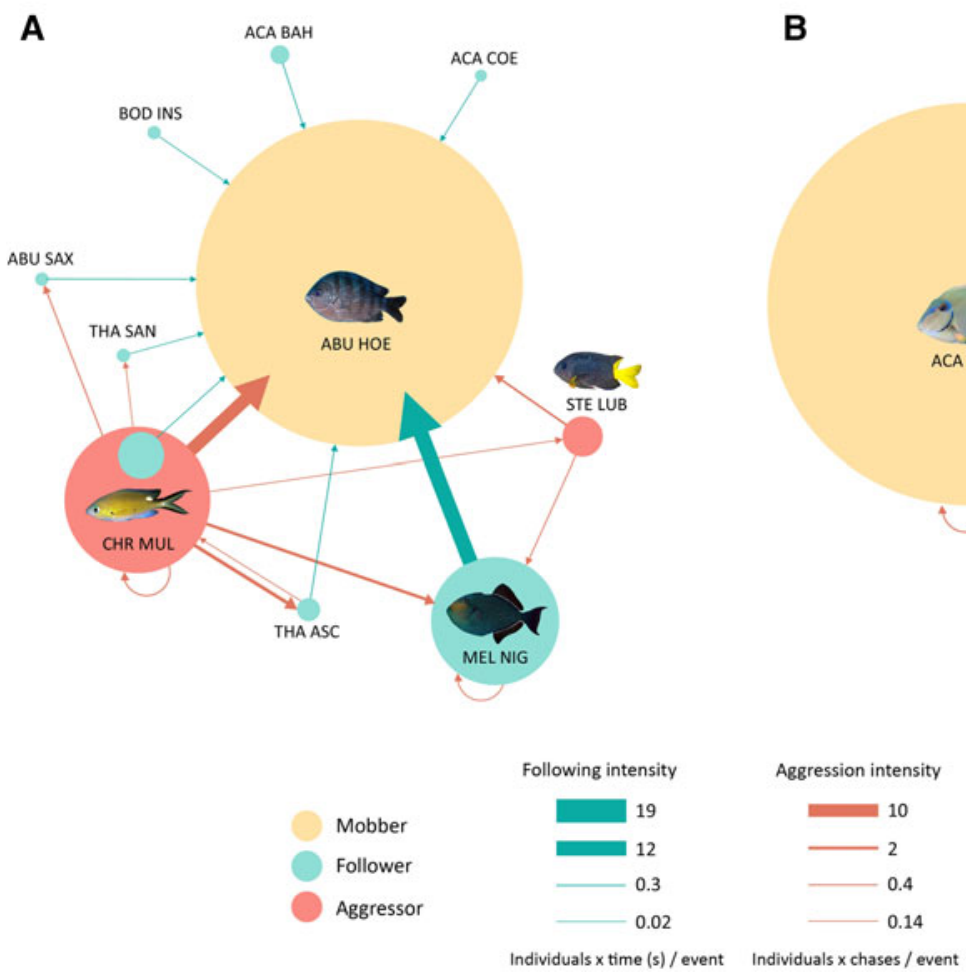

Acanthurus spp. mobs

B
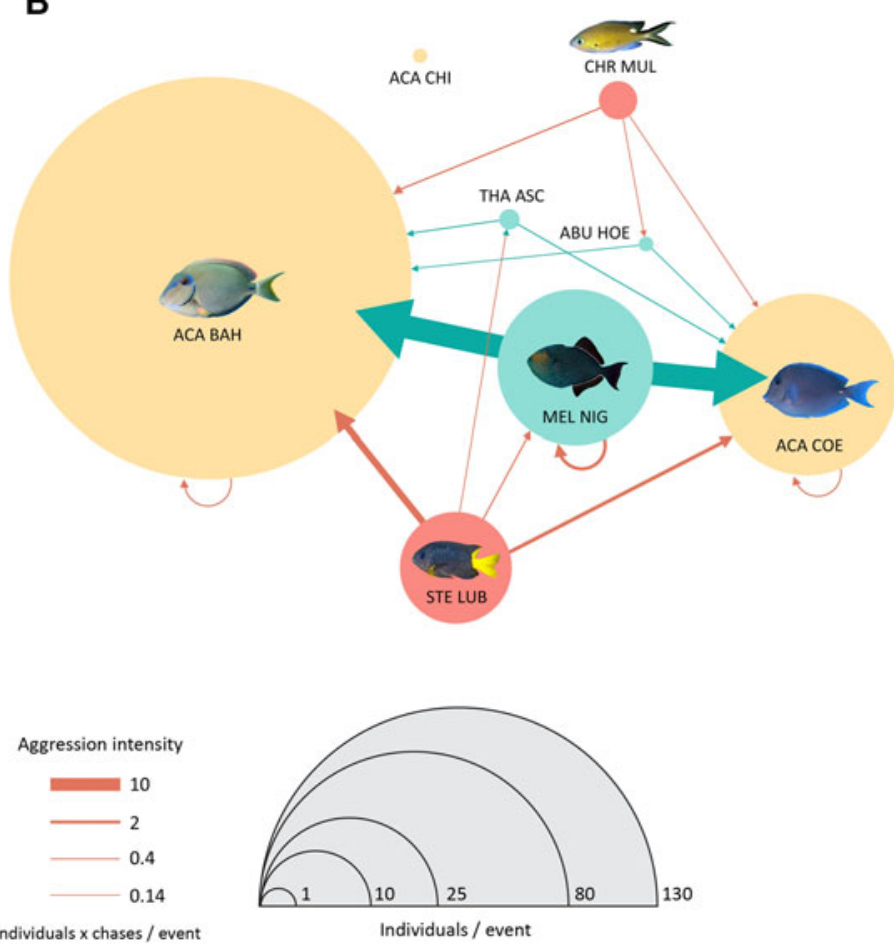

Fig. 6. Interaction networks during events of nuclear-follower mobs led by (A) the African sergeant (Abudefduf hoefleri) and (B) surgeonfish (Acanthurus spp.). Colours indicate behaviour types recorded during the mobbing events (circles) or the interaction types (arrows). Size of circles indicates the abundance of each species during the events and arrows' thickness indicates the intensity of the interactions. Acronyms are abbreviated species names.

South Atlantic Ocean. The existence of unreported and possibly unique behaviours, such as the mob-feeding behaviour reported here by the African sergeant (Abudefduf hoefleri), indicates that isolated islands might generate not only endemic species, but also distinct behaviours and interactions (Lubbock, 1980; Price \& John, 1980; Bingeman \& Bingeman, 2005; Wirtz et al., 2017). Additionally we add to the few scattered comments on Ascension Island's fish associations by presenting new records and quantifying both cleaning and mob-feeding interactions.

\section{Cleaning interactions}

We found only facultative cleaners at Ascension (sensu Côté, 2000; Grutter, 2005; Francini-Filho \& Sazima, 2008). The only obligate fish cleaners in the Atlantic are gobies of the genus Elacatinus, which occur in four oceanic islands in the South-western Atlantic (Fernando de Noronha and Atol das Rocas, Sazima et al., 2008; Batista et al., 2012; and Trindade and Martim Vaz, Gasparini \& Floeter, 2001; Guimarães et al., 2004), but are absent in both the Mid-Atlantic Ridge Islands (Lubbock, 1980; Lubbock \& Edwards, 1981; Edwards \& Glass, 1987; Feitoza et al., 2003) and the Tropical Eastern Atlantic (Wirtz et al., 2007; Quimbayo et al., 2012). It is possible that due to the absence of obligate cleaners in some oceanic islands, the cleaner role is taken over by facultative cleaners, some of which are endemic to these islands. For instance, eight facultative cleaner species, including two endemics are recorded at St Tomé and Príncipe in the Eastern Atlantic (Quimbayo et al., 2012) and two facultative cleaners, including one endemic, are recorded at Azores in the North Atlantic (Bertoncini et al., 2009). In the more isolated Ascension Island, we observed that three of the five cleaners are endemic to the Mid-Atlantic Ridge, Ascension and St Helena or to Ascension only. As far as we know, there is no clear evidence of obligate cleaning habitats for the widely distributed white-striped cleaner shrimp. The available data suggest that its colour pattern is similar to obligate cleaner fishes (Limbaugh et al., 1961) and that it has high cleaning efficiency (Jonasson, 1987). We therefore cautiously opted to consider this shrimp as a facultative cleaner until detailed observational and diet studies are available about its cleaning role.

In our study, contribution to total cleaning events was unrelated to cleaner abundance. Juvenile Island hogfish and French angelfish contributed mostly to cleaning events but had low abundance. This might be an outcome of these species' contrasting colour pattern (e.g. Cheney et al., 2009), capable of drawing more attention from client fishes and from divers compared with the butterflyfish and the wrasse. Juveniles of other Bodianus species and the French angelfish are active cleaners in many places, even in some where obligate lineages do occur (e.g. Johnson \& Ruben, 1988; Wicksten, 1998; Sazima et al., 1999, 2010c; Luiz et al., 2008). For instance, at the coastal Abrolhos Archipelago, in Brazil, the French angelfish has a cleaning role similar to that of the obligate cleaner barber goby (Elacatinus figaro), both of them tending cleaning stations and cleaning a speciesrich assemblage of clients (Sazima et al., 2010b).

Most of the client types we recorded at Ascension, namely damselfish, triggerfish, goatfish, sea chub, squirrelfish, groupers 
and morays, conform to the types (even if not always the same species) habitually recorded at other oceanic islands in the Atlantic (Gasparini \& Floeter, 2001; Sazima et al., 2005; Francini-Filho \& Sazima, 2008). On the other hand, the green sea turtle is rarely recorded as a client at oceanic islands. This turtle is cleaned by a wrasse at Trindade Island (Gasparini \& Floeter, 2001) and by two damselfish and two surgeonfish at the Fernando de Noronha Archipelago (Sazima et al., 2010a).

\section{Mob-feeding behaviour}

We recorded several instances of mobbing at Ascension. Surgeonfishes mobbed while feeding over algal turfs and sandy patches on and around Lubbock's damselfish territories. The barber surgeonfish (Acanthurus bahianus) occurs at Ascension, St Helena and on the Brazilian coastal shelf and oceanic islands (Bernal \& Rocha, 2011). Albeit abundant and usually performing feeding mobs at some coastal sites in Brazil (e.g. Arraial do Cabo, Ferreira et al., 2004), the only South-western Atlantic oceanic island where this species is common is Trindade Island, where it does not form such feeding groups or mobs (Gasparini \& Floeter, 2001). The low abundance of aggressive territorial pomacentrids at Trindade (Pinheiro et al., 2011) could be a factor influencing the absence of mobs despite the great numbers of this surgeonfish. At Ascension, the high abundance of the endemic Lubbock's damselfish (our personal communication) might force surgeonfish to group into mobs to maximize feeding rate per individual. Single species mobs of the barber surgeonfish have also been observed at St Helena, where the St Helena damselfish (Stegastes sanctaehelenae) occurs in high densities (J. Brown personal communication).

Contrary to surgeonfish mobs, feeding mobs of sergeant fish (genus Abudefduf) have not been reported to occur naturally to date at least in the Atlantic. Reproductive males of the sergeant major (Abudefduf saxatilis) guarding nests and driven away by passing scuba divers had their nests attacked by groups of opportunistic conspecifics (Cheney, 2008). The same species displays group-feeding while clearing sites for nesting at St Paul's Rocks (Francini-Filho et al., 2012). Both these events involve blue coloured, reproductive males feeding constantly at the same flat or vertical surface for many minutes prior to egg-laying by females (Francini-Filho et al., 2012). These behaviours, although superficially similar, are fundamentally distinct from the one we report here for the African sergeant A. hoefleri: (1) the mobs we recorded were unrelated to divers' presence, as shown by their occurrence on remote filming; (2) they did not feed continually over a particular area, but rather for $10-20 \mathrm{~s}$ and then moving away; and (3) the darkened, not bluish, colour and vigorous swimming movements with both the pectoral and caudal fins were conspicuous. The dark colour of mobbing individuals sharply contrasts with the intense blue colouration of African sergeants observed alone (Vella et al., 2016).

The African sergeant (Abudefduf hoefleri) was formerly known only from the Eastern Atlantic (Loris \& Rucabado, 1990; Wirtz et al., 2007; Espino et al., 2015). Therefore, we extend its range to Ascension and also report its mob-feeding behaviour for the first time.

Sergeant fishes are omnivorous generalists, switching between plankton and benthic feeding depending on resource availability (Randall, 1967; Sazima et al., 2006). During the mob-feeding events, the African sergeant was chased much more by the brown chromis (Chromis multilineata) than by the Lubbock's damselfish (Stegastes lubbocki) (Figure 6). The brown chromis is a seasonally territorial species (sensu Ridley, 1978) during its reproductive period when males defend their brood vigorously (Myrberg et al., 1967; Ridley, 1978). Therefore, we believe that the African sergeants are opportunistically exploring algal turfs from Lubbock's damselfish territories but apparently concentrate on the brown chromis's egg clutches, a highly energetic resource. Although spawns could not be observed from the analysed videos, African sergeants' foraging bouts were concentrated along near-vertical surfaces, consistent with micro-habitats preferred for spawning by pomacentrids in general (Montgomery, 1981). Moreover, eggs of the brown chromis are minute and not organized in compact masses such as those from other pomacentrids (Myrberg et al., 1967) and therefore hardly visible to the human eye.

We also suggest that the darkened colouration of the African sergeant could help it avoid aggressions from the brown chromis while in their territories. This could occur by resembling harmless species (from a reproductive male brown chromis' point of view) such as the detritivorous barber surgeonfish or by resembling the numerically dominant blackfish (Melichthys niger). This type of similarity, called aggressive mimicry, has been described for a variety of fish species (Ormond, 1980; Sazima, 2002; Randall, 2005), always in the form of a mimic predating on adult individuals. If the suspected egg predation is confirmed, it would add a previously undocumented facet to aggressive mimics. The blackfish is the most abundant species in Ascension's reefs and around other oceanic islands in the Atlantic, such as Trindade and St Paul's Rocks, attaining swarming abundances (Lubbock, 1980; Price \& John, 1980; Gasparini \& Floeter, 2001; Brewin et al., 2015; Wirtz et al., 2017). On some occasions, we observed group-feeding behaviour by the blackfish (Figure $4 \mathrm{D}$ ) without attracting attention from aggressor species such as Lubbock's damselfish or the brown chromis. We suggest that the sheer numeric dominance by the blackfish would result in decreased aggressiveness towards it, which would benefit a potential mimic. The groups of darkened yellow goatfish (Mulloidichthys martinicus) perhaps take advantage of mimicry as well, e.g. social or Batesian mimicry (Randall, 2005). We are, however, unable to offer a proper explanation for this colour, as we have not recorded the goatfish joining other similarly coloured fishes, or evading predators while in the dark attire. Some shoaling fish species adopt a dark colour while defending resources, hunting or mating (DeLoach, 1999; Sazima et al., 2013) and this may be another possibility for darkening in the yellow goatfish.

At Ascension, feeding frenzies by the blackfish are readily observable even from above water (Lubbock, 1980): when an unpredicted food source is made available, these fish are always the first to reach it, similarly to what was described at Fernando de Noronha by Sazima et al. (2003). Such frenzies occur in other South Atlantic islands (e.g. Gasparini \& Floeter, 2001; Sazima et al., 2003), but their unprecedented group size at Ascension is reflected in the fact that this species was the most important follower of both types of feeding mobs in our study (Figure 6). Kavanagh \& Olney (2006) suggest that, among the factors that contribute to the swarming abundances of the blackfish (Melichthys niger) in isolated islands, its exceptionally long pelagic stage and high plasticity in feeding might be crucial for its success. We add that its 
adaptability and ability to quickly perceive its surroundings could be just as important. For example, at Fernando de Noronha Archipelago large groups of blackfish associate with groups of spinner dolphins (Stenella longirostris) and follow these cetaceans to feed on their faeces. The fish are even able to recognize a dolphin that is about to void and quickly converge in large groups of up to 300 individuals on a particularly rich discharge (Sazima et al., 2003).

\section{CONCLUSIONSAND NEW PERSPECTIVES}

In our study, cleaning activities were performed exclusively by facultative fish species that cleaned disproportionally to their abundance. Either the white-striped cleaner shrimp (Lysmata grabhami) is able to display a specialized cleaning role in Ascension island or this reef community subsists without any obligate cleaner. If this absence of obligate cleaners is confirmed, it could be explained by non-specialized (or less specialized) cleaners being able to control isolated islands' species poorer fish parasite assemblages. There is compelling evidence that simplified reef food webs have smaller parasite richness than the more complex ones (Lafferty et al., 2006, 2008; Wood et al., 2014). Although this has not, to our knowledge, been assessed by experimental design in isolated islands $v s$ continental areas, it seems reasonable to assume that simplified food webs of isolated islands contain fewer parasite species than coastal sites. Further studies on community dependence of cleaners in isolated islands and continental areas might help to clarify these issues. An interesting question to be hereafter addressed would be how non-isolated reefs such as those from mainland Africa are able to sustain themselves in the absence of obligate cleaner fishes (Quéro et al., 1990).

Mob feeders, especially the African sergeant, showed darkened colours, a possible mimicry strategy to take advantage of the sheer numeric dominance of the blackfish. We propose that mimicry might help the sergeants to approach the brown chromis territories without being perceived as a threat, or being perceived as a threat unworthy of fighting for, until very close. This would allow the sergeants to draw more resources from brown chromis' reproductive territories. A new avenue would be to understand the reliance of African sergeant on mobs for feeding and if brown chromis' eggs are in fact an important food resource for this sergeant species.

Cleaning, mobbing, following and other multi-species fish associations are poorly studied in isolated islands such as Ascension. These places are poorer in species than coastal reefs and provide the opportunity for plastic species to take on new ecosystem roles and perform unique behaviours. For instance, the widespread Western and Eastern Atlantic chain moray (Echidna catenata) is reported to strike at sally lightfoot crabs (Grapsus grapsus) out of the water and chase them on the exposed reef at ebb tide only at the oceanic Fernando de Noronha Island (Sazima \& Sazima, 2004). The same applies to the circumtropical blackfish group-feeding on wastes of spinner dolphins at the same island (Sazima et al., 2003). Recording and reporting such opportunistic or symbiotic relationships might help, for example, to better understand marine species' degree of adaptability in face of newly set environmental and biological conditions. This is particularly promising in the case of isolated islands, where there is increased probability that the species involved in such associations are endemics. Additional and perhaps surprising examples of associations, interactions and behaviours certainly are waiting to be formally recorded (see Losey, 1978 for an instrumental definition and examples of multispecies symbiotic behaviours).

\section{SUPPLEMENTARY MATERIAL}

The supplementary material for this article can be found at http://dx.doi.org/10.1017/Soo25315416001041.

\section{ACKNDWLEDGEMENTS}

We are indebted to the Conservation Department of the Ascension Island Government, Ascension Divers and Obsidian Hotel for all of the support they provided. In particular, we wish to thank Caroline Yon for providing us with full membership of the Ascension Dive Club, Dr Nicola Weber for crucial help with permits and logistics, Emma Nolan and Kate Downes for invaluable support during our island time. We appreciate the help of all of the Conservation Department team. Samara Danielski analysed the remote videos in search of cleaning and mobbing events. We also greatly benefitted from the critical comments and suggestions of three anonymous referees.

\section{FINANCIAL SUPPDRT}

This study was funded by the Brazilian National Council of Research and Development $(\mathrm{CNPq})$ through grant no. 458548/2013-8 to Dr Leticia Veras Costa Lotufo; and by the California Academy of Sciences to LR and SB.

\section{REFERENCES}

Arnal C., Verneau O. and Desdevises Y. (2006) Phylogenetic relationships and evolution of cleaning behaviour in the family Labridae: importance of body colour pattern. Journal of Evolutionary Biology 19 , $755-763$.

Aronson R.B. (1983) Foraging behavior of the West Atlantic Trumpetfish, Aulostomus maculatus: use of large, herbivorous reef fishes as camouflage. Bulletin of Marine Science 33, 166-171.

Barlow G.W. (1974) Extraspecific imposition of social grouping among surgeonfishes (Pisces: Acanthuridae). Journal of Zoology 174, 333-340.

Batista H., Veras D., Oliveira P., Oliveira D., Tolotti M., Marins Y., Zill J., Pereira R., Hazin F. and Silva M. (2012) New records of reef fishes (Teleostei: Perciformes) in the Rocas Atoll Biological Reserve, off Northeastern Brazil. Check List 8, 584-588.

Bernal M.A. and Rocha L.A. (2011) Acanthurus tractus Poey, 1860, a valid western Atlantic species of surgeonfish (Teleostei, Acanthuridae), distinct from Acanthurus bahianus Castelnau, 1855. Zootaxa 2905, 63-68.

Bertoncini Á.A., Machado L.F., Barreiros J.P., Hostim-Silva M. and Verani J.R. (2009) Cleaning activity among Labridae in the Azores: the rainbow wrasse Coris julis and the Azorean blue wrasse Centrolabrus caeruleus. Journal of the Marine Biological Association of the United Kingdom 89, 859-861. 
Bingeman J. and Bingeman J. (2005) Ascension Island: inshore sea life Sandown: Coach House Publications.

Brewin P.E., Brown J. and Brickle P. (2015) Diurnal variation of fish and macrobenthic invertebrate community structure in an isolated oceanic island of the South Atlantic. Journal of the Marine Biological Association of the United Kingdom 96, 737-747.

Cheney K.L. (2008) Non-kin egg cannibalism and group nest-raiding by Caribbean sergeant major damselfish (Abudefduf saxatilis). Coral Reefs 27,115 .

Cheney K.L. and Côté I.M. (2003) The ultimate effect of being cleaned does ectoparasite removal have reproductive consequences for damselfish clients? Behavioral Ecology 14, 892-896.

Cheney K.L., Grutter A.S., Blomberg S.P. and Marshall N.J. (2009) Blue and yellow signal cleaning behavior in coral reef fishes. Current Biology $19,1283-1287$.

Côté I.M. (2000) Evolution and ecology of cleaning symbioses in the sea. Oceanography and Marine Biology: An Annual Review 38, 311-355.

Craig M.T. and Hastings P.A. (2007) A molecular phylogeny of the groupers of the subfamily Epinephelinae (Serranidae) with a revised classification of the Epinephelini. Ichthyological Research 54, 1-17.

Dawson M.N. (2016) Island and island-like marine environments. Global Ecology and Biogeography 25, 831-846. doi: 10.1111/geb.12314.

DeLoach N. (1999) Reef fish behavior: Florida, Caribbean, Bahamas. Jacksonville: New World Publications.

Edwards A.J. and Glass C.W. (1987) The fishes of Saint Helena Island, South Atlantic Ocean. Journal of Natural History 21, 617-686.

Espino F., Tuya F. and Brito A. (2015) Occurrence of the African Sergeant, Abudefduf hoefleri (Steindachner, 1881) (Actinopterygii Pomacentridae) in the Canary Islands Waters. Revista de la Academia Canaria de Ciencias 26, 83-89.

Feitoza B.M., Rocha L.A., Luiz-Júnior O.J., Floeter S.R. and Gasparini J.L. (2003) Reef fishes of St. Paul's Rocks: new records and notes on biology and zoogeography. Aqua, Journal of Ichthyology and Aquatic Biology 7, 61-82.

Ferreira C.E.L., Floeter S.R., Gasparini J.L., Ferreira B.P. and Joyeux J.C. (2004) Trophic structure patterns of Brazilian reef fishes: a latitudinal comparison. Journal of Biogeography 31, 1093-1106.

Floeter S.R., Krohling W., Gasparini J.L., Ferreira C.E.L. and Zalmon I.R. (2007a) Reef fish community structure on coastal islands of southeastern Brazil: the influence of exposure and benthic cover. Environmental Biology of Fishes 78, 147-160.

Floeter S.R., Vázquez D.P. and Grutter A.S. (2007b) The macroecology of marine cleaning mutualisms. Journal of Animal Ecology 76, 105-111.

Foster S.A. (1985) Group foraging by a coral reef fish: a mechanism for gaining access to defended resources. Animal Behaviour 33, 782-792.

Francini-Filho R.B., Coni E.O.C., Ferreira C.M., Alves A.C., Rodrigues L.S. and Amado-Filho G.M. (2012) Group nest clearing behavior by the Sergeant Major Abudefduf saxatilis (Pisces: Pomacentridae) Bulletin of Marine Science 88, 195-196.

Francini-Filho R.B. and Sazima I. (2008) A comparative study of cleaning activity of two reef fishes at Fernando de Noronha Archipelago, tropical West Atlantic. Environmental Biology of Fishes 83, 213-220.

Gasparini J.L. and Floeter S.R. (2001) The shore fishes of Trindade Island, western South Atlantic. Journal of Natural History 35, 1639-1656.

Gasparini J.L., Luiz O.J. and Sazima I. (2008) Cleaners from the underground. Coral Reefs 27, 143-143.

Grutter A.S. (2005) Cleaning mutualism in the sea. In Rohde K. (ed.) Marine parasitology. Collingwood: CSIRO Publishing, pp. 264-278.
Guimarães R.Z.P., Gasparini J.L. and Rocha L.A. (2004) A new cleaner goby of the genus Elacatinus (Teleostei?: Gobiidae), from Trindade Island, off Brazil. Zootaxa 8, 1-8.

Itzkowitz M. (1979) The feeding strategies of a facultative cleanerfish, Thalassoma bifasciatum (Pisces: Labridae). Journal of Zoology 187, 403-413.

Janasson M. (1987) Fish cleaning behaviour of shrimp. Journal of Zoology 213, $117-131$.

Johnson W.S. and Ruben P. (1988) Cleaning behavior of Bodianus rufus, Thalassoma bifasciatum, Gobiosoma evelynae and Periclimenes pedersoni along a depth gradient at Salt River Submarine Canyon, St. Croix. Environmental Biology of Fishes 23, 225-232.

Karplus I. (2014) Symbiosis in fishes: the biology of interspecific partnerships. Chichester: John Wiley \& Sons.

Kavanagh K.D. and Olney J.E. (2006) Ecological correlates of population density and behavior in the circumtropical black triggerfish Melichthys niger (Balistidae). Environmental Biology of Fishes 76, 387-398.

Keenleyside M.H.A. (1979) Diversity and adaptation in fish behaviour. Berlin: Springer-Verlag.

Krajewski J.P. and Floeter S.R. (2011) Reef fish community structure of the Fernando de Noronha Archipelago (Equatorial Western Atlantic): the influence of exposure and benthic composition. Environmental Biology of Fishes 92, 25-40.

Lafferty K.D., Dobson A.P. and Kuris A.M. (2006) Parasites dominate food web links. Proceedings of the National Academy of Sciences USA 103, 11211-11216.

Lafferty K.D., Shaw J.C. and Kuris A.M. (2008) Reef fishes have higher parasite richness at unfished Palmyra atoll compared to fished Kiritimati Island. EcoHealth 5, 338-345.

Lehner P.N. (1979) Handbook of ethological methods. New York, NY: Garland STPM Press.

Limbaugh C., Pederson H. and Chace F.A.C. Jr (1961) Shrimps that clean fishes. Bulletin of Marine Science of the Gulf and Caribbean 11, 237-257.

Longo G.O., Ferreira C.E.L. and Floeter S.R. (2014) Herbivory drives large-scale spatial variation in reef fish trophic interactions. Ecology and Evolution 4, 4553-4566.

Longo G.O. and Floeter S.R. (2012) Comparison of remote video and diver's direct observations to quantify reef fishes feeding on benthos in coral and rocky reefs. Journal of Fish Biology 81, 1773-1780.

Loris D. and Rucabado J. (1990) Pomacentridae. In Quéro J.C., Hureau J.C., Karrer C., Post A. and Saldanha L. (eds) Check-list of the fishes of the eastern tropical Atlantic (CLOFETA). Lisbon and Paris: JNICT, SEI, UNESCO, pp. $842-850$.

Losey G.S. (1972) The ecological importance of cleaning symbiosis. Copeia 1972, 820-833.

Losey G.S. (1978) The symbiotic behavior of fishes. In Mostofsky D.I. (ed.) The behavior of fish and other aquatic animals. New York, NY: Academic Press, pp. 1-31.

Lubbock R. (1980) The shore fishes of Ascension Island. Journal of Fish Biology 17, 283-303.

Lubbock R. and Edwards A. (1981) The fishes of Saint Paul's Rocks. Journal of Fish Biology 18, 135-157.

Luiz O.J.J., Carvalho-Filho A., Ferreira C.E.L., Floeter S.R. and Sazima I. (2008) The reef fish assemblage of the Laje de Santos Marine State Park, Southwestern Atlantic. Zootaxa 25, 1-25.

Lukoschek V. and McCormick M.I. (2000) A review of multi-species foraging associations in fishes and their ecological significance. 
Proceedings of the Ninth International Coral Reef Symposium I, 467474.

Montgomery W.L. (1981) Mixed-species schools and the significance of vertical territories of damselfishes. Copeia 1981, 477-481.

Myrberg A.A., Brahy B.D. and Emery A.R. (1967) Field observations on reproduction of the damselfish, Chromis multilineata (Pomacentridae), with additional notes on general behavior. Copeia $1967,819-827$.

Nelson J.S. (2006) Fishes of the world. Hoboken, NJ: John Wiley \& Sons.

Ormond R.F.G. (1980) Aggressive mimicry and other interspecific feeding associations among Red Sea coral reef predators. Journal of Zoology 191, 247-262.

Pinheiro H.T., Ferreira C.E.L., Joyeux J.C., Santos R.G. and Horta P.A. (2011) Reef fish structure and distribution in a south-western Atlantic Ocean tropical island. Journal of Fish Biology 79, 1984-2006.

Price J.H. and John D.M. (1980) Ascension Island, South Atlantic: a survey of inshore benthic macroorganisms, communities and interactions. Aquatic Botany 9, 251-278.

Quéro J.C., Hureau J.C., Karrer C., Post A. and Saldanha L. (1990) Check-list of the fishes of the eastern tropical Atlantic (CLOFETA). Lisbon and Paris: JNICT, SEI, UNESCO.

Quimbayo J.P., Floeter S.R., Noguchi R., Rangel C.A., Gasparini J.L., Sampaio C.L.S., Ferreira C.E.L. and Rocha L.A. (2012) Cleaning mutualism in Santa Luzia (Cape Verde Archipelago) and São Tomé Islands, Tropical Eastern Atlantic. Marine Biodiversity Records 5, e118.

Quimbayo J.P., Zapata F.A., Floeter S.R., Bessudo S. and Sazima I. (2014) Reef fish foraging associations at Malpelo Island, Colombia (Tropical Eastern Pacific). Boletín de Investigaciones Marinas $y$ Costeras 43, 183-193.

Randall J.E. (1967) Food habits of reef fishes of the West Indies. Studies of Tropical Oceanography 5, 665-847.

Randall J.E. (2002) Surgeonfishes of Hawaii and the world. Honolulu: Mutual Publishing and Bishop Museum Press.

Randall J.E. (2005) A review of mimicry in marine fishes. Zoological Studies 44, 299-328.

Randall J.E. and Randall H.A. (1960) Examples of mimicry and protective resemblance in tropical marine fishes. Bulletin of Marine Science of the Gulf and Caribbean 1, 444-480.

Reinthal P.N. and Lewis S.M. (1986) Social behaviour, foraging efficiency and habitat utilization in a group of tropical herbivorous fish. Animal Behaviour 34, 1687-1693.

Ridley M. (1978) Paternal care. Animal Behaviour 26, 904-932.

Robertson D.R. (2001) Population maintenance among tropical reef fishes: inferences from small-island endemics. Proceedings of the National Academy of Sciences USA 98, 5667-5670.

Robertson D.R., Sweatman H.P.A., Fletcher E.A. and Cleland M.G. (1976) Schooling as a mechanism for circumventing the territoriality of competitors. Ecology 57, 1208-1220.

Sazima C., Bonaldo R.M., Krajewski J.P. and Sazima I. (2005) The Noronha wrasse: a "jack-of-all-trades" follower. Aqua, Journal of Ichthyology and Aquatic Biology 9, 97-108.

Sazima C., Grossman A. and Sazima I. (2010a) Turtle cleaners: reef fishes foraging on epibionts of sea turtles in the tropical Southwestern Atlantic, with a summary of this association type. Neotropical Ichthyology 8, 187-192.

Sazima C., Guimarães P.R., Reis S.F. and Sazima I. (2010b) What makes a species central in a cleaning mutualism network? Oikos 119, 1319-1325.
Sazima C., Krajewski J.P., Bonaldo R.M. and Sazima I. (2007) Nuclear-follower foraging associations of reef fishes and other animals at an oceanic archipelago. Environmental Biology of Fishes $80,351-361$.

Sazima I. (2002) Juvenile snooks (Centropomidae) as mimics of mojarras (Gerreidae), with a review of aggressive mimicry in fishes. Environmental Biology of Fishes 65, 37-45.

Sazima I., Carvalho-Filho A. and Sazima C. (2008) A new cleaner species of Elacatinus (Actinopterygii: Gobiidae) from the Southwestern Atlantic. Zootaxa 1932, 27-32.

Sazima I., Grossman A. and Sazima C. (2010c) Deep cleaning: a wrasse and a goby clean reef fish below $60 \mathrm{~m}$ depth in the tropical southwestern Atlantic. Marine Biodiversity Records 3, e6o.

Sazima I., Krajewski J.P., Bonaldo R.M. and Sazima C. (2013) A vida dos peixes em Fernando de Noronha. Campinas: Editora Terra da Gente.

Sazima I., Moura R.L. and Sazima C. (1999) Cleaning activity of juvenile angelfish, Pomacanthus paru, on the reefs of the Abrolhos Archipelago, western South Atlantic. Environmental Biology of Fishes $56,399-407$.

Sazima I. and Sazima C. (2004) Daytime hunting behaviour of Echidna catenata (Muraenidae): why chain morays foraging at ebb tide have no followers. Aqua, Journal of Ichthyology and Aquatic Biology 8, 1-8.

Sazima I., Sazima C. and Silva J.M. Jr (2003) The cetacean offal connection: feces and vomits of spinner dolphins as a food source for reef fishes. Bulletin of Marine Science 72, 151-160.

Sazima I., Sazima C. and Silva J.M. Jr (2006) Fishes associated with spinner dolphins at Fernando de Noronha Archipelago, tropical Western Atlantic: an update and overview. Neotropical Ichthyology 4, $451-455$.

Sikkel P.C. and Hardison P.D. (1992) Interspecific feeding associations between the goatfish Mulloides martinicus (Mullidae) and a possible aggressive mimic, the snapper Ocyurus chrysurus (Lutjanidae). Copeia 1992, 914-917.

Soares M.C., Bshary R., Cardoso S.C., Côté I.M. and Oliveira R.F. (2012) Face your fears: cleaning gobies inspect predators despite being stressed by them. PLOS ONE 7, 3-8.

Sun D., Cheney K.L., Werminghausen J., Meekan M.G., McCormick M.I., Cribb T.H. and Grutter A.S. (2015) Presence of cleaner wrasse increases the recruitment of damselfishes to coral reefs. Biology Letters 11, 20150456.

Vella A., Vella N. and Darmanin S.A. (2016) The first record of the African Sergeant, Abudefduf hoefleri (Perciformes: Pomacentridae), in the Mediterranean Sea. Marine Biodiversity Records 9, 15.

Vermeij G.J. (2004) Island life: a view from the sea. In Lomolino M.V. and Heaney L.R. (eds) Frontiers of biogeography: new directions in the geography of nature. Sunderland, MA: Sinauer Associates, pp. 239-254.

von Eibl-Eibesfeldt I. (1955) Über Symbiosen, Parasitismus und andere besondere zwischenartiliche Beziehungen tropischer Meeresfische. Zeitschrift für Tierpsychologie 12, 203-219.

Wicksten M.K. (1998) Behaviour of cleaners and their client fishes at Bonaire, Netherlands Antilles. Journal of Natural History 32, 13-30.

Wirtz P., Bingeman J., Bingeman J., Fricke R., Hook T.J. and Young J. (2017) The fishes of Ascension Island, central Atlantic Ocean new records and an annotated checklist. Journal of the Marine Biological Association of the United Kingdom 97, 783-798.

Wirtz P., Ferreira C.E.L., Floeter S.R., Fricke R., Gasparini J.L., Iwamoto T., Rocha L., Sampaio C.L.S. and Schliewen U.K. (2007) 
Coastal fishes of São Tomé and Príncipe islands, Gulf of Guinea (Eastern Atlantic Ocean) - an update. Zootaxa 1523, 1-48.

and

Wood C.L., Sandin S.A., Zgliczynski B., Guerra A.S. and Micheli F. (2014) Fishing drives declines in fish parasite diversity and has variable effects on parasite abundance. Ecology 95, 1929-1946.

\section{Correspondence should be addressed to:}

R.A. Morais

Marine Macroecology and Biogeography Lab,

Departamento de Ecologia e Zoologia,

Centro de Ciências Biológicas,

Universidade Federal de Santa Catarina,

Florianópolis - SC, Brazil, Postal code: 88040-900

email: renatomoraisaraujo@gmail.com 